\section{Growth Response of 20 Seed Geranium Cultivars to Three Day- Night Temperature Regimes}

\author{
Mark S. Strefeler \\ Department of Horticultural Science, University of Minnesota, 305 Alderman \\ Hall, 1970 Folwell Avenue, St. Paul, MN 55108
}

Additional index words. day-night temperature differential, height control, node count

\begin{abstract}
The influence of temperature and genotype on plant height, internode length, and morphological development of 20 cultivars of Pelargonium $\times$ hortorum Bailey were determined by growing plants under one of three day-night temperature regimes $(18 / 18 C$, $18 / 24 \mathrm{C}$, and $24 / 18 \mathrm{C}$ ). Temperature regime influenced internode length and plant height regardless of plant genotype. Internode length and plant height increased as the day-night temperature differential (DIF) increased from -6 to 6C. Average internode length increased from $5.3 \pm 0.2 \mathrm{~mm}$ for $-6 \mathrm{C}$ DIF to $6.3 \pm 0.2 \mathrm{~mm}$ for $+6 \mathrm{C}$ DIF. Genotypes differed for average internode length $(4.2$ to $8.7 \mathrm{~mm})$ and plant height $(54$ to $95 \mathrm{~mm})$. Node count increased as average daily temperature (ADT) increased. Node counts were 11.2 at 18/18C $(A D T=18), 11.9$ at 24/18C $(A D T=20.3)$, and 12.1 at 18/24C $(A D T=21.8)$. Genotype $\times$ temperature interactions were not significant for the recorded traits. This study demonstrates that DIF is an effective height control strategy, regardless of geranium genotype, and that DIF combined with the selection of genetically short cultivars may eliminate the need for chemical height control in the commercial production of geraniums.
\end{abstract}

Recently, geranium growers have applied differential temperature regimes to control plant height (Erwin, 1991; Erwin and Schwarze, 1991; Erwin et al., 1989; Heins et al., 1988). Although reports on the response of geraniums to day and night temperatures have been published (Erwin and Schwarze, 1991; Pytlinski and Krug, 1988; White and Warrington, 1984a, 1984b, 1988), the responses of a variety of Pelargonium $\times$ hortorum cultivars to day-night temperature regimes have not been investigated. I report on the genotype $\times$ temperature regime interaction of diverse geranium cultivars.

\section{Materials and Methods}

Four seed geranium cultivars were selected from each of five cultivar series [Avanti (Clause Semences Professionnelles, Brétigny-Sur-Orge, Cedex, France); Elite, Multibloom, Orbit (Goldsmith Seeds, Gilroy, Calif.); and Pinto (S\&G, Fort Wayne, Ind.). Cultivars with scarlet or white flowers were selected from each series and the remaining cultivars were randomly selected from a limited supply of seed used for bedding plant trials (see Table 1). Seedlings of the selected geranium cultivars were transplanted into $10-\mathrm{cm}\left(450 \mathrm{~cm}^{3}\right)$, round, azalea pots filled with a commercial peat-

Received for publication $27 \mathrm{Feb}$. 1995. Accepted for publication 18 July 1995. Scientific Journal Series Paper 20,857, Minnesota Agricultural Expt. Station, St. Paul. Igratefully acknowledge Robert Quené, Debra Schwarze, and David Larson for their valuable assistance. The cost of publishing this pape was defrayed in part by the payment of page charges. Under postal regulations, this paper therefore must be hereby marked advertisement solely to indicate this fact. based medium (Bacto Pro Plant Mix, Michigan Peat Co., Houston). Plants were grown under standard cultural practices at a constant $18 \pm 2 \mathrm{C}$ under ambient light for 2 weeks before initiating temperature treatments.

Plants were placed in a $18 \pm 2 \mathrm{C}$ or $24 \pm 2 \mathrm{C}$ greenhouse section for application of temperature treatments. Actual measured air temperatures averaged over $24 \mathrm{~h}$ were 19.6 and $24.8 \mathrm{C}$, respectively. Plants were spaced pot to pot until leaves touched and then were spaced to 25 plants $/ \mathrm{m}^{2}$ for the remainder of the study. Plants were moved at 0800 and 1700 HR daily to provide the three day-night temperatures: 0 DIF (18/18C), -DIF (18/24C), and +DIF (24/ 18C). Photoperiod cloth was used to maintain a 9-h photoperiod. The study was conducted from 25 Mar. to 19 May (54 days).

At the start of this study, the youngest leaf was marked with a punched hole and all data were collected on growth above this node. Data on internode length, plant height, and node count were collected on 19 May 1992 above the marked leaf. Average internode length was calculated by dividing the plant height above the marked leaf by the number of nodes formed above that leaf. A randomized complete-block design with two blocks and two plants per block was used. Blocks consisted of separate benches in each greenhouse section. Analysis of variance was conducted to determine the effect of cultivar and daynight temperature regimes on the variables listed. Data were analyzed using Systat for Macintosh (Systat, Evanston, Ill.).

\section{Results and Discussion}

Cultivar and temperature regime had significant $(P<0.001)$ independent effects on average internode length, node count, and plant height, but their interaction was not significant. The average internode length for plants grown under $+\mathrm{DIF}, 0 \mathrm{DIF}$, and $-\mathrm{DIF}$ was $6.3 \pm 0.2,5.8 \pm 0.2$, and $5.3 \pm 0.2 \mathrm{~mm}$, respectively. Average internode length was significantly $(P<0.01)$ different among all treatments. Internode length and plant height decreased as DIF decreased from 6 to $-6 \mathrm{C}$. This trend was consistent with those reported for Lilium longiflorum L. (Erwin et al., 1989; Heins et al., 1988) and Campanula isophylla Moretti (Moe et al., 1991)

Node count per plant varied significantly $(P \leq 0.05)$ among treatments: 11.2 at $0 \mathrm{DIF}$, 11.9 at + DIF, and 12.1 at - DIF. Node count increased as average daily temperature increased. These results are consistent with previous reports of the effects of temperature on geranium growth and development (Erwin, 1991; Erwin and Heins, 1992; White and Warrington, 1984a, 1984b).

Avanti series cultivars were taller than any other cultivars (Table 1). 'Red Elite' had the shortest internode length and plant height. Cultivars that were tallest and had the longest internodes under + DIF were taller than other cultivars, regardless of the DIF treatment. Variation among some cultivars within a series for internode length, plant height, and number of nodes was small but significant (Table 1).

Meancomparisons(single-degree-of-freedom contrasts) of plant height above the marked leaf showed that the Avanti series was significantly $(P \leq 0.01)$ taller (mean height $85 \mathrm{~mm})$ than any other series. Plants from Pinto and Elite series were significantly shorter than plants of the other series; mean plant heights were 59 and $62 \mathrm{~mm}$, respectively. Mean plant heights of the Multibloom and Orbit series were 70 and $68 \mathrm{~mm}$, respectively. The same pattern was observed for differences in average internode length among series. Average internode lengths for Avanti, Multibloom, Orbit, Elite, and Pinto series were 7.8, 6.2, 5.7, 5.2 , and $4.8 \mathrm{~mm}$, respectively. Node count also varied among series: Elite, Orbit, and Pinto series plants $(12.0,12.3,12.4$, respectively) had significantly $(P \leq 0.05)$ more nodes than those from Avanti and Multibloom (10.9 and 10.8 , respectively). Differences in plant height were primarily due to differences in internode length rather than node count because the tallest cultivar series had the fewest number of nodes.

Using DIF to control plant height and internode length of seed geraniums is effective regardless of the plant genotype. Differences in cultivar internode length and plant height indicate that cultivar selection is an integral part of any height control strategy in commercial seed geranium production. Selecting cultivars that tend to have shorter internodes and a higher rate of node formation in conjunction with judicious use of DIF should facilitate the production of high-quality seed geraniums with little or no chemical height control.

For the plant breeder, the lack of a genotype $\times$ day-night temperature regime interaction indicates that selection for reduced inter- 
node length and, therefore, reduced plant height can be achieved regardless of the day-night temperature regime used for selection. Variability among cultivars for internode length

and plant height suggests that additional progress in breeding for shorter internode length and plant height can be realized with current germplasm.

Table 1. Mean internode length, plant height, and node count of 20 seed geranium cultivars.

\begin{tabular}{lccc}
\hline \hline Series and cultivar & Internode length $(\mathrm{mm})^{\mathrm{z}}$ & Plant ht $(\mathrm{mm})$ & Node count \\
\hline Avanti & & & \\
Lilac Rose & $7.2 \mathrm{ab}^{\mathrm{y}}$ & $86 \mathrm{a}^{\mathrm{y}}$ & $11.9 \mathrm{a}^{\mathrm{y}}$ \\
Red & $8.7 \mathrm{~b}$ & $95 \mathrm{a}$ & $11.0 \mathrm{a}$ \\
Salmon & $7.0 \mathrm{a}$ & $81 \mathrm{a}$ & $11.6 \mathrm{a}$ \\
Scarlet & $8.4 \mathrm{c}$ & $78 \mathrm{a}$ & $9.4 \mathrm{~b}$ \\
Elite & & & \\
Red & $4.2 \mathrm{a}$ & $54 \mathrm{a}$ & $12.8 \mathrm{a}$ \\
Salmon & $6.1 \mathrm{~b}$ & $65 \mathrm{~b}$ & $10.6 \mathrm{~b}$ \\
Scarlet & $5.2 \mathrm{c}$ & $64 \mathrm{~b}$ & $12.3 \mathrm{a}$ \\
White & $5.1 \mathrm{c}$ & $62 \mathrm{~b}$ & $12.3 \mathrm{a}$ \\
Multibloom & & & \\
Red & $6.6 \mathrm{a}$ & $69 \mathrm{a}$ & $10.6 \mathrm{a}$ \\
Salmon & $6.2 \mathrm{a}$ & $65 \mathrm{a}$ & $10.5 \mathrm{a}$ \\
Scarlet & $6.0 \mathrm{a}$ & $74 \mathrm{a}$ & $12.3 \mathrm{~b}$ \\
White & $6.2 \mathrm{a}$ & $62 \mathrm{a}$ & $10.0 \mathrm{a}$ \\
Orbit & & & \\
Red & $5.5 \mathrm{a}$ & $73 \mathrm{a}$ & $13.3 \mathrm{a}$ \\
Salmon & $6.2 \mathrm{~b}$ & $73.3 \mathrm{a}$ & $11.8 \mathrm{bc}$ \\
Scarlet & $5.6 \mathrm{a}$ & $71.2 \mathrm{a}$ & $12.6 \mathrm{c}$ \\
White & $5.5 \mathrm{a}$ & $64.0 \mathrm{~b}$ & $11.5 \mathrm{~b}$ \\
Pinto & & & $12.5 \mathrm{a}$ \\
Quicksilver & $4.4 \mathrm{a}$ & $55 \mathrm{a}$ & $12.9 \mathrm{a}$ \\
Scarlet & $5.5 \mathrm{~b}$ & $71 \mathrm{~b}$ & $12.8 \mathrm{a}$ \\
Violet & $4.4 \mathrm{a}$ & $56 \mathrm{a}$ & $11.5 \mathrm{~b}$ \\
White & $4.8 \mathrm{a}$ & $55.1 \mathrm{a}$ & \\
\hline
\end{tabular}

${ }^{2}$ Average internode length was calculated by dividing plant height by number of nodes. ${ }^{y}$ Mean separation within a cultivar series at $P \leq 0.01$. Mean separation by single-degree-of-freedom contrasts $(n=4)$.

\section{Literature Cited}

Erwin, J.E. 1991. The effect of day and night temperature on zonal geranium flower development. Minn. Flower Growers Bul. 40(2):16-19.

Erwin, J.E. and R.D. Heins. 1992. Environmental effects on geranium development. Minn. Flower Growers Bul. 41(1):1-9.

Erwin, J.E., R.D. Heins, and M.G. Karlsson. 1989. Thermomorphogenesis in Lilium longiflorum. Amer. J. Bot. 76(1):47-52.

Erwin, J.E. and D. Schwarze. 1991. The effects of day and night temperature on zonal geranium flower and peduncle dry weight. Minn. Flower Growers Bul. 40(3):1-3.

Heins, R.D., J.E. Erwin, and M.G. Karlsson. 1988. Use temperature to control plant height. Greenhouse Grower 6(9):32-37.

Moe, R., R.D. Heins, and J.E. Erwin. 1991. Stem elongation and flowering of the long-day plant Campanula isophylla Moretti in response to day and night temperature alterations and light quality. Scientia Hort. 48:141-151.

Pytlinski, J. and H. Krug. 1988. Modeling Pelargonium zonale response to various day and night temperatures. Acta. Hort. 248:75-84.

White, J.W. and I.J. Warrington. 1984a. Effects of splitnight temperatures, light, and chlormequat on growth and carbohydrate status of Pelargonium xhortorum. J. Amer. Soc. Hort. Sci. 109:458-463.

White, J.W. and I.J. Warrington. 1984b. Growth and development responses of geranium to temperature, light integral, $\mathrm{CO}_{2}$, and chlormequat. J. Amer. Soc. Hort. Sci. 109:728-735.

White, J.W. and I.J. Warrington. 1988. Temperature and light integral effects on growth and flowering of hybrid geraniums. J. Amer. Soc. Hort. Sci. 113:354-359. 